\title{
CO-GOVERNANCE, SOCIAL RESPONSIBILITY AND ECONOMIC DEMOCRACY
}

\begin{tabular}{|c|c|}
\hline \multirow{3}{*}{ Abstract } & Peter Zdravje* \\
\hline & School of Advanced Social Studies in Nova Gorica, Slovenia \\
\hline & $\begin{array}{l}\text { This article contributes to the justification of social responsibility and economic democracy, which can create a sustainable soci- } \\
\text { ety through co-governance in companies. Each of these areas is specifically described as well as the contribution of each to a } \\
\text { sustainable society. Importantly, the message that capital, which predominates in the current socio-economic system, does not } \\
\text { allow the development of co-governance of stakeholders in companies. This severely curtails the making of socially responsible } \\
\text { decisions in companies, which does not contribute to the development of economic democracy. By equating the rights of labour } \\
\text { owners with the rights of capital, the conditions of co-governance of stakeholders would be met, which would give them the right } \\
\text { to self-actualization based on the results of their work. This would lead to the development of economic democracy and further } \\
\text { to a sustainable society. A sustainable society, supported by the co-governance, social responsibility and economic democracy } \\
\text { is the ultimate goal of society. }\end{array}$ \\
\hline Keywords & co-governance $\cdot$ social responsibility $\cdot$ economic democracy $\bullet$ stakeholders $\cdot$ risk $\cdot$ sustainable society. \\
\hline
\end{tabular}

\section{Introduction}

An article by the Gostiša $(2021,16-17)$, in which he discusses the internal ownership of employees and economic democracy, encourages expansion and in-depth thoughts beyond the author's thinking. In the article, the author writes about economic democracy, as well as about social responsibility and co-decision or co-governance by employees.

The real challenge has become the research question: What is the synergy as a basis that influences the development of society to achieve the ultimate goal a sustainable society? And another related question: What is the importance of cogovernance, social responsibility and economic democracy in creating a sustainable society?

The questions are focused only on companies and the observed areas are addressed only within business framework. They are addressed through an extensive review of selected literature, where critical considerations of information have already been found.

These questions are not just economic issues. They reach into the field of economic sociology, where "accelerates the
1 The word co-governance is not the same as co-management, although it is also very often used in translations that do not distinguish between management and governance. Rozman explains: "Owners-shareholders have started to employ professionals called managers to manage their companies. The once unified function of governance (and management) has been divided into two organizational functions: governance, making decisions to protect owners' interests, and management, coordinating business activities in a most efficient way while striving to attain goals and execute policies set by governance." (Rozman 2000, 95) Later he explains: "The goal remained profitability, and corporate governance was conducted on the basis of ownership but not necessarily by the owners themselves. This was the first form of 'non-owners' or 'nonself-governance'. Corporate governance and management went separate." (Rozman 2013, 4)

Clarke (1998, 182-194 as cited in Rozman 2013, 6) recalls of different stakeholders' governance similar processes in the past, like mutual funds, cooperatives, Mondragon cooperatives, Israeli kibbutzes and Yugoslav self-governance.

"Corresponding author e-mail: peter@zdravje.in

(C) 2021 Peter Zdravje. This is an open access article distributed under the Creative Commons Attribution-NonCommercial-NoDerivs license (c) B BY

(http://creativecommons.org/licenses/by-nc-nd/4.0/) 
transition from dissemination and consideration of context to the formation of actually alternative, socially based descriptions and explanations of economic actions." (Zelizer 2012, 840) It is characteristic of the considered areas that these changes are happening not only in local economic space. These are not experiments of local significance. Changes or alternative social changes are happening on a global level too. This paper deals with each area separately and seeks out the synergies that operate between them. In dealing with co-governance, the relationship between labour ownership and capital, social responsibility in companies, and what influences the development of economic democracy are explored.

The purpose of this paper is also to determine the importance and interconnectedness of the areas discussed, and how the processes of connections take place.

In the conclusion, the findings on where synergies between the descussed areas can lead are shown in Figure 1. The paper is a continuation of Gostiša's thinking and a contribution to creating a common path to the ultimate goal, a sustainable society. For the emergence and existence of economic democracy, the necessary condition is met, which are regulated ownership relations and the introduction of approaches to the self-actualization of employees.

\section{Co-governance}

In the Republic of Slovenia, the right of workers to co-decision is guaranteed in Article 75 of the Constitution of the Republic of Slovenia (Official Gazette of the Republic of Slovenia, No.: 33/91): "This justifies the right to co-governance."

In some places, it is still possible to trace the doubts some individuals in the public sphere have about the functioning of co-governance because they have experience of the previous period of the socialist socio-economic system, where self-governance applied. This system has had a long period of validity in Slovenia and evokes unpleasant memories that limit the distinction between self-governance and co-governance and underlines the need to understand the latter. Nowadays, it is important for owners, managers and employees to be aware of the differences. The participation of all the listed participants in business processes in companies also depends on the understanding of the differences.

On the basis of the Constitution of the Republic of Slovenia, the operation of co-governance in Slovenian companies is legally determined in the Workers Participation in Management Act (WPMA), adopted in July 1993 (Worker Participation in Management Act, 42/07) and last consolidated in 2007. Article 1 of the Act "determines the ways and conditions for the participation of employees in the management of companies, regardless of the form of ownership, sole proprietors with at least 50 employees and cooperatives. The law restricts the co-governance of employees in companies with more than 50 employees, thus eliminating the legal right to co-govern employees in micro (up to ten employees) and small (up to fifty employees) companies (Companies Act, 18/2021). The legal regulation that takes into account the interests of all participants in the company's business process is regulated in such a way as to provide capital owners with the opportunity to assert their interests through the company's governing bodies. Managers are given great independence in decision-making in relation to the company's bodies. Employees have the opportunity to assert their interests in governance decisions, but they do not have the opportunity to supervise. The interests of external participants in the company's business processes are also legally protected. (Gostiša s. a., 3) To the

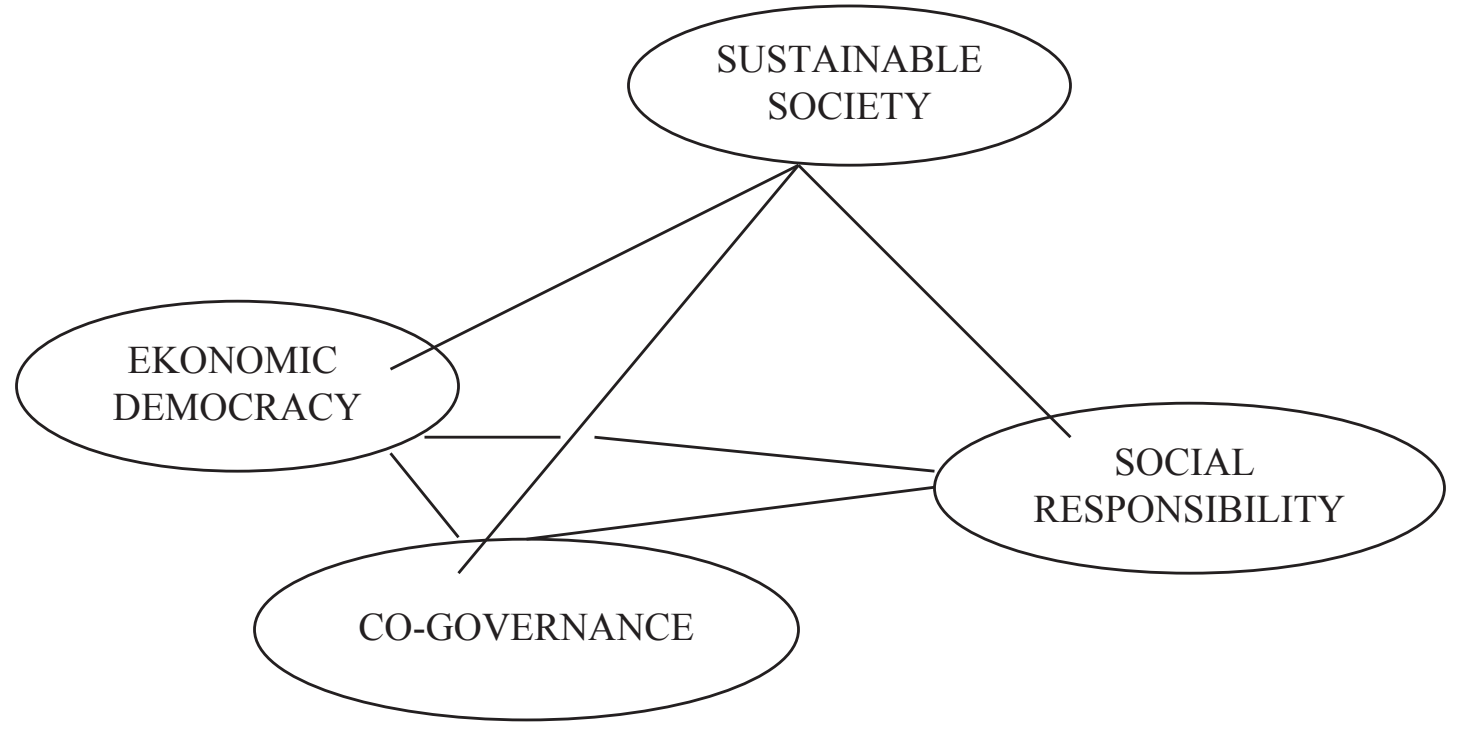

Figure 1. The trinity of a sustainable society. 
owners of capital, employees represent the necessary labor force for the production of products or services.

In order to operate to produce the final product or service, each company needs business process elements, which are working capital, objects of work, services used and employees with their own workforce. The latter represents the knowledge and skills of employees. Employees with their work in companies represent one of the essential production elements of business processes. They are important stakeholders, regardless of capital investment. Freeman wrote that "we view stakeholders as any person, group or organization who affects and / or is impacted by an organization's decisions." (Freeman, 1984 as cited in Wilson, Bunn and Savage 2010, 78)

By entering the production processes of companies, employees perform their work and assume the relatively greatest risk. The investor or the owner of the company invests his capital in the means of production and assumes the risks with his capital investment. This risk is fully recognized socially in classical and neoclassical capitalism. The majority opinion that the greatest risk is borne by the investor of the capital investment is considered only as an excuse to enable the investor to appropriate the profit. Employees also create added value in production processes, but with their intellectual capital, without which these production processes would not take place. The Slovenian legal system does not adequately regulate employee risk, which is borne by all employees entering into an employment relationship. Through work, they gain a livelihood and an important social and personal identity. Work is not only a source of income with which they can afford goods, it is also a source of feeling pride in how much they realize their ideas through working in a company. By losing their job in the company, they lose their income and may cause a sense of failure in life, which can affect their health.

This means that employees also need to be seen as stakeholders which is a broader concept than the employees themselves. The broadest definition of stakeholders covers those who have their own interests in the company. These can be individuals or groups, such as employees, shareholders, company management, creditors, customers, suppliers, banks, trade unions, the state, stock exchanges, financial and potential investors. Jančič says that stakeholders are all those who have any kind of relationship with a company, are connected to its policy and practice, influence it and have a share in a company that is not necessarily owned. (Jančič 1999, 114 as cited in Fajić 2010, 321) Bergant cites the opinion of the author Boatright, who states that "stakeholders are defined more generally, for example, as "groups that are important to the existence and performance of the association" or as "groups or individuals that may influence or be affected by the operations of the association" (Boatright, 2000 as cited in Bergant, 2021a, 770). Further, Bergant finds out that the classification of stakeholders is important in terms of the content of reporting required by the IESBA Code (The International Ethics Standards Board for Accountants) in point 220 (IESBA, 2018) as well (Bergant, 2021a, 770). Nevertheless, this paper focuses only on the stakeholders in the company. The presented divisions of stakeholders can be very easily divided into two groups, namely external (e.g. suppliers, customers, banks) and internal (e.g. shareholders, management, employees) stakeholders. However, such a division is not appropriate for answering research questions. The interest of stakeholders in the company is important for the discussion of corporate social responsibility. In their business decisions, companies are socially responsible not only to shareholders in the stakeholder group, but to all stakeholders. There is the question why the company should be accountable to stakeholders. Bergant states that »Every contribution to the creation of added value should be properly evaluated and rewarded. The contribution to the creation of value added also means the contribution to the reduction of business risk or to its management« (Bergant 2021a, 771) Employees, management and owners are the three main groups in companies that influence the performance of their business through their internal operations. Their joint action is co-governance. Failure to take into account the business interests of any of these three groups increases the risk for all three groups and, of course, for external stakeholders as well. This jeopardizes the successful operation of the company and the risk in the face of fierce competition can even be so great that it threatens the existence of the company. It is therefore important to constantly consider the material, social and personal needs of all groups, especially employees, one of the most important elements of the business process. This ensures the co-governance of employees who co-decide on business decisions through works councils, employee representatives on company boards and trade unions. Some employees participate in these bodies of governance and supervision of the company's operations, and supervision is understood as a counterbalance to the interests of investors. The performance of employees in governing bodies is often at odds with the performance of investors, i.e. business owners, and also at odds with managers appointed by business owners. The business decisions of these two groups of stakeholders most often emphasize short-term interests in order to achieve the earliest and greatest possible profits. However, this is not co-governance based on the socially responsible operation of the company.

Employees also have the option of additional forms of cogovernance based on ownership. They can acquire this in a variety of ways: their own cash investment, company profitsharing and an option to buy shares as a reward for work based on the decisions of their managers or owners. In this way, employees acquire internal ownership of the company in which they are employed. Internal ownership is thus 
recognized as part of the rights of employees (henceforth stakeholders). When entering a company's work process, internal ownership is not automatically given to employees. They acquire the right to contribute their own cash share by negotiating with existing stakeholders in the company.

Co-governance is understood as a broader concept than internal ownership and derives from the right of stakeholders to take risks. Risk-taking gives the right to co-governant in the company, i.e. to influence business decisions. Bergant writes, "Co-governance does not mean making decisions, but the ability to influence decisions with the power of arguments." (Bergant 2018b, 7) Stakeholders have a legal right to influence decisions in companies through trade unions and, collective bargaining, but only to the extent determined by investors, capital investors. This is not fair and it is not ethical, as companies operate dependent on both capital and labour, which are equivalent elements of the business process.

Through co-governance, employees gain the opportunity for personal creation and personal development, which increases their power in the company and also the growing awareness of socially responsible business decisions. Increasing power is based on the cooperation of employees, managers and owners of the company in solving problems and joint strategic planning of company development: all of these groups need to make socially responsible decisions.

3. Social Responsibility

The idea of social responsibility has evolved from a relatively insignificant idea in the last few decades into a widely accepted approach to understanding both business and broader social responsibility. Bergant states where and who all talks about social responsibility:

Authors as well as international institutions in many ways define social responsibility. Among them is very important ISO standard with its seven principles: responsibility for the impact (accountability), transparency of data, ethical behavior, respect for interests of stakeholders, respect for the rule of law, respect for international norms of behavior and respect for human rughts (ISO 26000). (Bergant 2021b, 182)

Social responsibility is also defined by the international standard ISO 26000 , which speaks primarily about the social responsibility of organizations or companies, while also emphasizing the responsibility of the individual and their impact on society. The standard focuses on the responsibility of organizations to the sustainable development of organizations, to business partners, to employees, to the community and to the environment. Mulej and Štrukelj (2017) highlight seven principles that support the central concepts of the ISO 26000 standard: (1) jurisdiction or official responsibility (in the title ISO 26000 uses the term 'responsibility' and in principle the term 'accountability'); (2) survey or transparency; (3) ethics, respect for (4) the interests of stakeholders, (5) the rule of law, (6) international norms, and (7) human rights (Mulej and Štrukelj 2017, 298) The standard is strongly focused on corporate responsibility to all people in the company and those in the community. The community area means the local and regional area where the company operates. In the current era of global action, however, the community must be considered globally. The standard helps to create conditions for employee satisfaction, so that organizations, with the support of the local and wider community, would gain better conditions for obtaining long-term stabler revenues and easier operations. Social responsibility has been defined by authors in many ways. One of these definitions is particulary exact by Bergant:

In terms of the socio-economic system, social responsibility is reflected in the design of such a system, which increases the efficiency of society in generating added value and takes into account the interests of stakeholders in its distribution. The holder of this type of social responsibility is, in principle, the whole society, but the greatest part of responsibility lies on individuals who have impact on the formation and changes of the socioeconomic system. (Bergant 2018a, 1)

The fact is that today capitalism is the globally dominant socioeconomic system. Despite today's capitalistic system, the belief that labour is important for production processes and that it is the intellectual property of a company has become increasingly prevalent. Holders of intellectual knowledge are all individuals who participate in the business processes of the company and are treated as the intellectual capital of the company which ownes it as intelectual property. There is no doubt here that such an understanding of labor is not socially responsible. It could be even argued that human rights are violated by such an understanding and conduct.

There seems to be an increasing emphasis on corporate social responsibility as a result of strong human rights movements. Thus, in the field of the development of corporate social responsibility, the tendency to take greater account of the relations between employees, the environment and society can be traced in the world and partly in Slovenia in practice and in the literature. Theoretical thinking and incentives are aimed at raising awareness of companies and the wider society towards social responsibility. Chin tells from her many years of practical work in the field of social responsibility:

Companies get involved in corporate social responsibility as a way to strengthen their business goals and 
demonstrate a commitment to ethical work practices, safe working conditions and fair trade. There are many methods to achieve these goals, and success is often expressed quantitatively, "and adds that" quantitative success is important for all parties involved to cooperate willingly and achieve goals, but the heart and soul of effective social responsibility is primarily responsible for building relationships promoting opportunities for workers, especially women and girls in the workplace and in their communities. (Chin 2019, 27)

Increasingly, there is a critical view of the still valid but surviving opinion of profit as a fundamental goal of the company. The development goes in the direction of "stakeholder capitalism" (Kovač 2010) and the recognition of intellectual capital. These ideas are advanced in terms of emphasizing intellectual capital, which is placed on the same level as financial capital. Rodrik (2020) emphasizes that companies are influential in the development of social responsibility through their development of production. They are important for the development of overall social well-being. This raises the question (requirement) of running a business and making decisions. Namely, he believes that the disputable mentality is that only investors take risks with their capital investments. He notes, however, that more and more companies are aware of their social responsibility and at the same time take into account profits and their social role.

Opinions of various authors on social responsibility and the role of stakeholders in companies indicate the direction of development towards achieving a higher level of awareness of social responsibility of all participants in society: investors, stakeholders in companies, the state and other members of society. Such a development will make it possible to achieve a sustainable society. Brooks and Dunn emphasize awareness very well: "We can be a generation that remakes business and capitalism, putting ethics at the center of business, and business at the center of ethics, creating a way of understanding business in the world of the twenty-first century." (Brooks and Dunn 2018, 291)

An important contribution to the understanding of social responsibility is the definition of Bergant (2019): "Social responsibility is the responsibility of individuals and organizational systems of all forms and levels for the creation and distribution of added value, that is, in increasing the welfare of the whole society«. This definition emphasizes the social responsibility of both the organizational system and the social responsibility of the individual. It follows that the responsible action of the individual from the point of view of social responsibility is of key importance.

Just as the individual in society is an individual cell, each enterprise is an individual cell in the socio-economic system. Individuals who work in the company and are stakeholders (as we have defined them above) in companies can act socially responsible. The whole society is becoming more and more aware of socially responsible action. Following this statement, it is quite clear that stakeholders in companies take socially agreed measures, thus making companies socially responsible.

The substantive area of social responsibility is therefore advocacy and the establishment of co-governance in companies. Stakeholders in companies therefore have a direct responsibility to make business decisions that are socially responsible and thus direct the operation of companies in systemic socially responsible operations. Employees supervise the adoption and implementation of socially responsible business decisions through their activities in governing bodies. Individuals in companies therefore influence companies to act in a socially responsible manner in accordance with the measures.

The state, which is an important stakeholder and co-owner in some companies in the economy, plays an important role in the social responsibility as a stakeholder. Representatives of the state participate in general assemblies, where the management boards propose the amount of dividends in the distribution of profits. Governments, through their representatives, should base their demands and possible counter-proposals on the government's strategy for economic development and other parts of social development, for which it would allocate additional funds from dividends received. This would be a socially responsible action by any government.

\section{Economic Democracy}

In the last few decades after the collapse of the socialist socio-economic system, there has been a belief that the capitalist socio-economic system will more than satisfactorily resolve the economic problems that have arisen. Zelizer notes that: "institutional economists are shocked that markets themselves (laissez-faire) have failed to change post-socialist economies". (Zelizer 2012, 841) Today's capitalist system is surviving wage capitalism, where financial capital plays a key role. It will not be possible to achieve a more economically developed, fairer and socially responsible society with this socio-economic system.

The fact is that intellectual capital is becoming more widespread, which mainstream capitalism does not consider as equivalent to financial capital. Economists and economic sociologists are looking for appropriate ways out of the current situation. In addition to discussions and some examples from the practice of co-governance on the basis of internal coownership, and discussions of social responsibility, the theory of economic democracy is also emerging, which could point to a deep asymmetry as a feature of Western society: 
1. Where socio-political relations are organized democratically, political power is accountable to the citizens.

2. The economy is organized on fundamentally different and mostly undemocratic grounds. Employees do not elect their managers, business investment decisions are not the responsibility of the community and banking policies on the allocation of funds are determined by the banks themselves without elected representatives of the economy.

These generally established asymmetries in the Western world (perhaps even globally around the world) not only suggest, but already point out, that the economy urgently needs democratization. The discussion is about economic democracy, which would not only be nominally important. Its practical feasibility is important.

The basic premise of economic democracy was laid by William Petty, a pre-classical economist of the seventeenth century (the pioneer of classical political economy) with a statement later called Petty's axiom: "Work is the father of the product and the earth is its mother. We cannot say which is more important for the conception of a child: mother or father." (Gostiša 2021, 16) With today's terms, it is possible to express his land as a mother and father as work, both as means of production. Petty thus perfectly equated the two fundamental elements of the production process, as it is not possible to determine which of them contributed more to the final product. Today's view of the share of inputs in output is the same as Petty's axiom, but socio-economic systems do not recognize this. It is known from the history of economic development that the equality of labor and the means of production were not equated by either the slave-owning system, or feudalism, or capitalism. Socialism was a long-standing socio-economic system, the only one that even glorified labour above all other elements of the production process. All socio-economic systems ignored Petty's axiom and are essentially systems that introduced and maintained developmental imbalances. Further, development of the socio-economic system is possible in a return to Petty's axiom, that is, the logical equating of the two elements of the production process, labour and capital. This axiom is universal and should apply in any socio-economic system. By equalizing labour and capital and their owners, stakeholders and investors, a clear definition of joint decision-making and business process management can be arrived at. Gostiša argues that it is logical to establish complete "legal" equality of their owners regarding their position and rights both in the organization and management of "joint" production processes (i.e. equal co-governance of companies) and in the distribution of jointly created product (i.e. their actual contribution to the proportional share in the business results of the companies)." (Gostiša 2021, 16)
A socio-economic system in which people would recognize the equality of labour and capital through their proper functioning and through legal regulation would undoubtedly be socially responsible. Economic democracy is not a condition for co-governance. The right to co-govern companies should be given to the owners of labour, intellectual capital, basically upon accession to the production process and not only on the condition that they are also owners of capital. Gostiša nicely explains that "no one has the right to "resell the results or outputs of work at a profit" if he paid workers only wages / salaries, which by definition is only the market equivalent of inputs, not the actual output of labor « (Gostiša 2021, 17) Employees, with their ownership of the work according to economic and legal logic, should have every right to occupy an equal place in companies with all other owners. This equivalent position in the company should guarantee them the right to co-govern all the more so if there are also stakeholders with capital ownership.

Economic democracy has been researched by many scholarswho have reached different conclusions in their research. Johanis and Wolf define economic democracy more widely as a system of checks and balances on economic power and support for the right of citizens to actively participate in the economy regardless of social status, race, gender, etc. (Johanisova and Wolf 2012, 564)

Based on this definition of economic democracy, Johanisova and Wolf suggest six possible faces of economic democracy:

(1) Regulation of market mechanisms and corporate activities. Regulation is one of the most obvious paths to curbing economic power, hence we highlight the issue of deregulation vis a vis possible degrowth policies. A revision of the free-market paradigm is suggested. (2) Support for social enterprises. We discuss different forms of democratic governance within enterprises and suggest that co operative approaches, common in social enterprises, are better suited to a degrowth economy. (3) Democratic money creation processes, including pluralist community currencies, are suggested to counter economic power caused by the practice of fractional banking. (4) Reclaiming the commons (especially in their original sense as communal land stewardship systems) both conceptually and physically is seen by us as an important aspect of enhancing economic democracy. (5) Redistribution of income and capital assets is discussed as another approach to achieving economic democracy. (6) Finally, we suggest that a broader view of economic democracy would involve a diversity of production scales and modes, including small-scale, subsistence and self employment. (Johanisova and Wolf 2012, 562) 
The proposed faces of the possible development of economic democracy show the possibilities of democratic growth in a democratic sustainable society.

"The term economic democracy has been in use since the 1920s to describe and discuss democratic governance within enterprises operating in a market setting. In the more mainstream versions of this approach, workers are encouraged to become share-owners in the company where they work." state Johanisova and Wolf $(2012,565)$. The authors see this as an opportunity for employees to acquire the right to co-govern on the basis of the purchase of company shares. They become shareholders and thus maintain the paradigm of the dominance of capital over labor, where the principle of one share - one vote applies. Their co-governance is only declarative and undemocratic, as they do not have as many shares - votes as the owners of the company and therefore cannot participate as equal stakeholders in making business decisions.

O'Neill explores the position of John Rawls, one of the most important philosofers of the late twentieth century, who addressed the issue of democracy in the workplace in his book "Justice and Fairness". In this book of his, where he discussed Marx's critique of liberalism, Rawls demonstrated his openness to radical anti-capitalist ideas, which at the time was considered Rawls's a very surprising position. (O'Neill 2008, 32)

O'Neill (Idib., 32) marvels, "how strongly Rawls is involved in the debate over the attractiveness and possibilities of workers controlled by workers, and the possibility that the principles of "justice as fairness « would be feasible only in some form of socialism with collective ownership of the means of production. Rawls believes that the very possibility of creating a just society may depend first and foremost on resolving issues of control over economic production." Rawls's view can be understood as a focus on the imagined goals of socialism, as Rawls saw it. More importantly, he recognized justice and fairness in the ownership and supervision of employees over the means of production. It can be concluded that with democracy in the workplaces, he understood the possibility of employees' co-governance. In this way, however, he approached the equalization of labour as a means of production with equity.

Economic democracy is an upgrade where there is no dominance of capital over labor, nor does the opposite apply. In the current capitalist socio-economic system, the legal order still prevails, where the company is defined as the personal property of investors, owners of capital with all the associated rights. This means, however, that stakeholders who own labor do not have the same economic rights as owners of capital. When this "injustice" is eliminated, when human capital, as the most important factor of production and ownership of labour, receives the same systemically valid regulation as capital, and there is a general equalization of rights, it will be possible to speak of economic democracy. We believe that this can be achieved with political will and that it can be regulated without interfering with the market system.

By establishing equal economic rights for labour owners and capital owners, when the long-known Petty axiom is met - under the two primary production conditions of labour and land - a necessary condition, but not a sufficient condition for economic democracy, i. e. the recognition of cogovernance rights in companies from ownership of the work will be met. Economic democracy is not based solely on employee ownership. In an economic democracy, employees should also have the right to share the results of work by co-governance.

The employee shared ownership plan (ESOP) system cames very close to this theoretical model. This is a program where employees systematically and gradually buy company shares, usually on favourable terms. Ellerman describes in his later work that the originator of the ESOP idea was lawyer Kelso in the 1950s. Kelso feared that automation, which had been widely introduced in the American industry, would take up many jobs. In order to stabilize society, his idea was for people to make capital gains in addition to income from work. He believed that if capitalism is a good thing, capitalists should also be developed. Therefore, the ESOP system is portrayed as transforming workers into capitalists. (Ellerman 2019, 4) From today's point of view, it means that the employees of that time were given the possibility of ownership in their companies, but it did not equate them with business owners in terms of owning shares of companies and did not give them the possibility of co-governance.

Klaneček writes about many studies on the relationship between employee ownership and business operations, most of which focused on the ESOP system. Research finds that employee co-ownership and co-governance have a strong positive impact on competition between companies. (Klaneček 2010, 2) Klaneček cites Kandas's report that research in the United States has shown that employees after retirement from companies with an ESOP system have significantly higher pensions than former employees from companies without an ESOP system. (Kardas 2002 as cited in Klaneček 2010, 2) Ellerman explains the ESOP system, which is quite different from the other purchase of employee share purchase plans (ESPP). According to this method, employees use part of their salaries to buy shares at a reduced price. However, this is very slow and does not involve a particularly large shareholding in the company. (Ellerman 2019, 2)

The ESOP system has been developed in Slovenia and has its starting point in the American system, but is somewhat adapted to the conditions in the Slovenian economy. Elerman and Gonza explain that the ESOP in Slovenia is not based on a pension fund that holds shares in the parent company, as in the 
American system. A special cooperative has been established in our system, which is in the function of an equity fund. Membership in this cooperative is acquired only by employees of the company and democratic co-governance is based on the principle of one member - one vote. In the Slovenian ESOP system, ownership also comes with the right to co-governance, thus equating this right with the rights of other owners. (Elerman and Gonza 2021, 30) Authors Ellerman and Gonza go on to explain that "co-ownership models can be designed to strive for the principles of economic democracy - the proposal of the Slovenian ESOP model links the right to company value, the right to profit and the right to govern to employment in the company. In this way, these rights are inalienable from work, just as in a democratic system, every citizen has the inalienable right to a political vote." (Ellerman and Gonza 2021, 30)

It can be expected that the adoption of the ESOP system in Slovenia will significantly improve the possibilities of connecting co-governance, social responsibility and the development of economic democracy. This would also mean significant progress on the path to a sustainable society.

\section{Sustainable Society}

This paper deals with the search for and verification of some possibilities for the development of society on the basis of cogovernance, social responsibility and economic democracy. In all the researched areas, there are risks as in the lives of individuals and groups, and there are especially many different risks in the business world. As Kirn puts it "Risks are inextricably linked to development and change. Modern society is developmental, innovative and has therefore become a risky society." (Kirn 2000, 798) In his assertion, Kirn draws on Beck's earlier assertion that "a risk society is not an option that can be chosen or rejected in the course of political debate. " (Beck 1996, 27 as cited in Adam, Beck and van Loon 2000, 7) »Instead, it is an inescapable structural condition of advanced industrialization where the produced hazards of that system undermine and/or canceled the established safety systems of the provident state's existing risk calculation. « (lbid, 7) It is said very clearly that there are dangers in the development of society and this cannot be avoided.

Attempts to develop a sustainable society with the increasing use of renewable resources, protective management of nature, and awareness of excessive consumption of the natural resources of the planet, are undoubtedly constantly present risks that need to be minimized. Because there are risks in every development and it is not possible to choose between paths with risks or without risks. Authors Adam, Beck, and van Loon suggest that "we go beyond the risk and technology as mere social constructs and instead understand how specific technologies are lived as a social practice that creates the future and how certain risks are experienced, perceived, defined, mediated, legitimized and/ or ignored." (Adam, Barbara, Ulrich Beck and Joos van Loon $2000,6)$ Equal thinking is also needed to reduce the risks of synergies between co-governance, social responsibility and economic democracy on the path to development in a sustainable society.

The areas of the research in this paper are undoubtedly all on the path of development into a sustainable society. The path of this development is full of risks, as each development has its own risks and the development path itself cannot prevent risks.

The development of co-governance in companies involves social responsibility. Awareness of social responsibility does not mean that co-governers make decisions about getting more and more. Social responsibility is reflected in the fact that co-governers want to develop and grow into more and more socially responsible people. It has been a long way to develop to today's more or less socially responsible man or woman. Individuals make up the entire society, regardless of the form of ownership. From the beginning of society's existence and development, people have had to work. As Bergant writes "A sense of threat to existence is the origin of basic human needs. Risks are threatening humankind since time immemorial. The risk can be managed only by working." (Bergant 2021, 49) Work has therefore accompanied man since ancient times. However, it is not just through work that man can eliminate threats to his existence. Bergant continues: "Furthermore, a fundamental feature of the need for security is that it is in principle never satisfied. Therefore, we must constantly establish an appropriate reserve, which means the need for constant work." (lbid, 49)

People, however, did not remove the threat to their existence by work alone. By thinking and learning, they always want to overcome the current state of their knowledge and spirit. To this day, people have also developed a sense of narrower and wider community. For such a development, individuals had to develop and get to know themselves. Thus when individuals satisfied and realized their needs and potentials, they became self-actualized. Turnšek Mikačić explores the self-actualization of the employee's balanced energy, competencies and functions:

It establishes the principle and defines the factors of personality management only on the basis of actualization and personal growth only. Only with the work that suits the employee, if he fulfills his mission with it, he self-actualizes. The work of an individual never fully fulfills, liberates and makes happy if it is not spiritualized. The concept of only the actualization of personal growth presupposes that there is an inner strength in every 
person that leads an individual to growth, learning, improvement, change. Actualization of human potentials is enabled by creativity and growth, respect for the person here and now, giving meaning to experience. (Turnšek Mikačić 2018, 259-275)

In an environment of more and more self-actualized and socially responsible individuals who form appropriate groups in today's society, decisions in companies and personal decisions will be socially responsible. Along the way, people will take measures to promote the synergistic integration of all observed areas, despite the ever-present risks. The purpose of development is not development itself on the path to a sustainable society; the goal is to achieve a sustainable society. In the synergy of co-governance and social responsibility, economic democracy is developing, which is a characteristic of a sustainable society. The system of the trinity of a sustainable society is shown in Figure 1:

The areas of co-governance, social responsibility and economic democracy represent a trinity. They are interconnected. In the absence of a constant flow of links between them due to the realization of various risks, there is no sufficient basis for achieving a sustainable society. At the top of the pyramid there is a sustainable society, supported by the trinity that is the ultimate goal of society. Its main feature is that it is a desired goal that suits the vast majority of society members. The goal is not static. It follows changes in society and is a customizable, flexible goal. In the event of disconnection of one of the areas of the trinity, the operation of a sustainable society is disrupted.

A sustainable society is the goal of sustainable development. Bergant (2021b) warns: "In short, a sustainable society is not a "no-growth" society - it is rather a society that recognizes the limits of growth and looks for alternative means of improvement." (Bergant (2021b, 205)

It is expected that a sustainable society will be achieved in the intended path, determined by the characteristics that can also be the main characteristics of a sustainable society:

\section{Preserving nature}

2. Happy, personally and socailly responsible, respected, content and satisfied people

3. State-of-the-art technology

4. Happy family

5. The participation of people

6. Long-term business success

7. Responsible owners

8. Socially responsible values, culture, ethics and norms

9. Thoughtful consumerism

10 Diversity management

11. Universal basic income

12 Solidarity
13 Free time and leisure

14 Systems/orders (e.g. political, legal, economic, social, health)

15 Democracy

The above defined sustainable society can play an important role as a fundamental objective of people for their functioning and behavior. (Šarotar Žižek and Mulej, 2020 as cited in Bergant 2021, 206)

\section{Conclusion}

This paper provides answers to the research questions on ownership relations between the most important means of production, i.e. ownership of labour and capital through the review of the existing literature. Broad social recognition of ownership of the work of employees, i.e. their intellectual property upon their entry into the production process and not only on the basis of capital, will open the democratic possibility of co-governance in companies. It is expected that the employees, then the stakeholders, will take measures that are socially responsible. As a result, companies would behave socially responsibly on the basis of socially responsible business decisions. With co-governance, social responsibility and the introduction of approaches to self-actualization of employees, a period of economic democracy could be initiated. For the emergence and existence of economic democracy, it is necessary that a necessary condition is met, that is, regulated property relations. A sufficient condition for the establishment of economic democracy will act by exercising the right to socially responsible co-governance. The orderly operation of synergy among all three areas is shown in Figure 1. Then and only then will it be possible to reduce risks on the path towards social development. The path leads to a sustainable society, but with every risk comes development. Figure 1 shows as if this path leads straight ahead. It can be expected that, despite the reduced risks, this path will not be straight and short. It is important to distinguish and recognize that the paper addresses the goal, which is a sustainable society, and not only the path, which is sustainable development towards a sustainable society. Further, it is also pointed out that the existence of a sustainable society is conditioned by constant action and connection with the trinity (our observed areas) and action among them.

In determining the synergy of the discussed areas, there was also the determination of their importance in creating a sustainable society. Furthermore, a sustainable society cannot be achieved without taking into account social responsibility in all areas and levels of life. This finding applies on a global scale. Adopting and implementing socially responsible measures from the individual to groups in society, 
from one company to the entire industry, and so on to society as a whole, will to lead to a sustainable society. The point is not in taking action and human development in "more and more" but "to be more".

In further research into the functioning of the interplay of cogovernancet, social responsibility and economic democracy, it would be advisable to explore connections in terms of Industry 4.0 or even 5.0 .

\section{References}

Adam, Barbara, Ulrich Beck and Joos van Loon. 2000. The Risk Society and Beyond. Critical Issues for Social Theory. London: SAGE Publication. Accessed December 1, 2021. https://books. google.si/books?hl=sl\&lr=\&id=-L_5g_3c20kC\&oi=fnd\&pg=PP8\& $\mathrm{dq}=u l$ rich+beck+risk+society\&ots=RoNwQcvyfX\&sig=VmJ00SI3s 3CT8_gl2hCRWGdEncw\&redir_esc=y\#v=onepage \&q=ulrich $\% 20$ beck\%20risk\%20society\&f=false

Bergant, Živko. 2018a. „Capital, Labour, and Social Responsibility Viewpoint of Economy and Society « $13^{\text {th }}$ Conference of Social Responsibility. Maribor. Accesed November 5, 2021. http://www.irdo. si/irdo2018/referati/c-01-bergant.pdf

Bergant, Živko. 2018b. „Notranje poročanje z vidika soupravljanja« Ekonomska demokracija. 6(7): 7-10.

Bergant, Živko. 2019. „Individual Person and Social Responsibility « 14th Conference of Social Responsibility, Maribor. Accesed November 5, 2021. http://www.irdo.si/irdo2019/referati/c-1bergant.pdf

Bergant, Živko. 2021a. "What and who is company's stakeholder?" International Journal of Science Academic Research. 02 (01). 770773 Accessed November 2, 2021. https://scienceijsar.com/sites/ default/files/article-pdf/IJSAR-0342.pdf.

Bergant, Živko. 2021b. Accountancy and Social Responsibility. An Innovative New Approach to Accountancy Theory and Practice. Cham, Switzeerland: Palgrave Macmillan

Brooks, J. Leonard and Paul Dunn. 2018. Business and Professional Efhics for Directors, Executives \& Accountants, 8th ed. Boston: Cengage Learning.

Chin, Motthida. 2019. "Be the Opportunity: The Heart and Soul of Corporate Social Responsibility." Journal of Fair Trade 1(1): 27-35. Accessed November 8, 2021. https://www.jstor.org/stable/10.13169/jfairtrade.1.1.0027.

Ellerman, David. 2019. "A Generic Model for Employee Stock Ownership Plans" Accesed May 6, 2020. https://www.researchgate.net/ profile/David_Ellerman/publication/322807430

Ellerman, David, and Tej Gonza. 2021. »Notranje lastništvo zaposlenih ni sinonim za ekonomsko demokracijo«. Delo, Sobotna priloga. Pisma bralcev. 11.9.2021: 29-30

Fajić, Amira. 2010. „Družbena odgovornost podjetij-ISO standardi 26000 «. In Zbornik 7. Festivala raziskovanja ekonomije in manage- menta. 321-327. Accessed November 8, 2021. Koper: Fakulteta za management.https://www.fm-kp.si/zalozba/ISBN/978-961-266122-9/prispevki/034.pdf

Gostiša, Mato. (Nano s.a.) »Udeleženci oziroma deležniki organizacije«. Accessed November 19, 2020. https://strokovniclanki. delavska-participacija.com/priloge/ID970306.doc

Gostiša, Mato. 2021. »Notranje lastništvo zaposlenih ni sinonim za ekonomsko demokracijo«. Delo, Sobotna priloga August 28 2021: 16-17.

ISO 26000: Social Responsibility. Accessed November 19, 2020. https://www.iso.org/iso-26000-social-responsibility.html

Johanisova, Nadia, and Stefan, Wolf. 2012. »Economic Democracy: A Path to the Future? « Futures. 44. 562-570. Accessed November 9, 2021.https://doi.org/10.1016/j.futures.2012.03.017

Kirn, Andrej. 2000. »Trajnostni razvoj in rizična družba». Teorija in praksa. 37 (5). 797-806

Klaneček, Alojz. 2010. »Integrativni Model Lastništva Zaposlenih« PhD.diss., Univerza na Primorskem, Faculty of Management.

Kovač, Bogomir. 2010. »Prerok v lastni deželi? « Mladina, April 30 2010. Accessed February 15, 2020. http://www.vzmd.si/novice/ mediji-o-malih-delnicarjih/prerok-v-lastni-dezeli.

Mulej, Matjaž, and Tjaša, Štrukelj. 2017. "Strategija podjetja in družbena odgovornost”. Revija za univerzalno odličnost. 6 (3): 292-307.

O’Neill, Martin. 2008. “Three Rawlsian Routes towards Economic Democracy”. Revue de philosophie économique. 8 (2): 29-55

Rodrik, Dani. 2020. "New Firms for a New Era". Social Europe (blog). Accessed February 19, 2020. https://www.socialeurope.eu/newfirms-for-a-new-era

Rozman, Rudi. 2000. »The Organizational Function of Governance: Development, Problems, and Possible Changes« Management: Journal of Contemporary Management Issues. 5 (2): 94-110. University of Ljubljana, Faculty of Economics.

Rozman, Rudi. 2013. Is There Another Way to The Future but A Utopian One? Dynamic Relationships Management Journal. May, 2013. University of Ljubljana, Faculty of Economics. 2(1): 3-14.

Turnšek Mikačić, Marija. 2018. "Nevrolingvistično programiranje kot orodje samo-aktualizacije posameznika in odsev v avtopoietski organizaciji”. Revija za univerzalno odličnost: RUO. 7 (3): 259-275. ISSN 2232-5204.

Ustava Republike Slovenije. 2000. Ljubljana: Delo.

Wilson, J. Elizabeth, Michele D. Bunn and Grant T. Savage. 2010. „Anatomy of a Social Partnership: A Stakeholder Perspective “ Industrial Marketing Management 39. 76-90.

Zakon o gospodarskih družbah (ZGD-1). Uradni list Slovenije, št. 18/2021. Accessed Oct 10, 2021. https://www.uradni-list.si/glasilo-uradni-list-rs/vsebina?urlurid=2021413

Zakon o sodelovanju delavcev pri upravljanju. Uradni list Republike Slovenije, št. 42/2007. Accessed October 10, 2021. http://pisrs.si/ Pis.web/pregledPredpisa?id=ZAKO5169

Zelizer, A. Viviana. 2012. „Preteklost in prihodnost ekonomske sociologije«. Teorija in praksa 49 (6). 838-853. 